\title{
Apparent digestibility of eelgrass Zostera marina by captive dugongs Dugong dugon in relation to the nutritional content of eelgrass and dugong feeding parameters
}

\author{
Kana Aketa ${ }^{1, *}$, Shiro Asano ${ }^{2}$, Yoshihito Wakai ${ }^{2}$ and Akito Kawamura ${ }^{1}$ \\ ${ }^{1}$ Aquatic Ecology Laboratory, Faculty of Bioresources, Mie University, Mie 514-8507, Japan \\ ${ }^{2}$ Toba Aquarium, Toba, Mie 514-8517, Japan
}

\begin{abstract}
The present study examined the digestibility of eelgrass based on dry weight and energy by captive dugongs Dugong dugon in relation to the nutritional content of the eelgrass and the feeding parameters of the dugongs. Digestibility was calculated on the basis that food retention by captive dugongs is 144-168 hours. Digestibility of eelgrass was strongly affected by the lignin content of the eelgrass species concerned, with a negative correlation between the apparent digestibility of a species and its lignin content. Since fiber contents are higher in seagrasses, including eelgrasses, than in terrestrial plants on which mammalian herbivores typically feed, the apparent digestibility reported from captive dugongs in the present study indicate that eelgrass may have an extraordinarily high digestibility.
\end{abstract}

Key words: apparent digestibility, dugong, eelgrass, lignin content, sirenians.

Dugongs Dugong dugon, a member of the sirenians, are found throughout subtropical and tropical waters of the Pacific and Indian Oceans (Bertram and Bertram 1973). They are one of the only surviving truly herbivorous marine mammals and feed mainly on seagrasses belonging to the Cymodoceae, the Hydrocharitaceae, the Potamogetonaceae and the Zosteraceae (Heinsohn and Birch 1972; Johnstone and Hudson 1981; Marsh et al. 1982; Erftemeijer et al. 1993; Aketa and Kawamura 2001). The seagrasses on which dugongs feed contain a higher proportion of fiber than the terrestrial plants consumed by terrestrial herbivores (Aketa et al. 2001).

Several studies on dugong and West Indian manatee Trichechus manatus digestion have been conducted, however, those by Murray et al. (1977), Best (1981), and Burn (1986) were based on analyses of the gastrointestinal contents of dead sirenians, whereas those of Lomolino and Ewel (1984), Aketa and Kawamura (2001), Aketa et al. (2001), and Aketa (2003) involved measurements of seagrass digestibility by live West Indian manatee and captive dugong. Aketa et al. (2001) clarified that there was no significant difference between male and female dugongs in terms of their capacity to digest seagrass (averaging 85-86\%). These studies indicated that digestibility by dugongs, and perhaps by other sirenians too, may be higher than any among terrestrial herbivores such as the horse $42.3 \%$ (Udén and Van Soest 1982).

It has long been known that the nutritional content of seagrasses changes in relation to their habitat and their growth (e.g. Harrison and Mann 1975; Ogawa and Sensyu 1986). Aketa et al. (2001), however, did not examine temporal changes in the apparent digestibility of seagrasses among captive dugongs, and information on temporal variation in the apparent digestibility of seagrasses among captive sirenians, and information on how sirenian feeding parameters affect digestibility, are generally lacking. Previous studies on temporal changes in apparent digestibility among terrestrial herbivorous mammals (Aagnes et al. 1995, 1996), indicate that digestibility among dugongs may also change seasonally, which may correspond with variation in the

${ }^{*}$ To whom correspondence should be addressed. Present address: Japan Wildlife Research Center, 3-10-10 Shitaya, Taito-ku, Tokyo 110-8676, Japan. E-mail: kaketa@jwrc.or.jp 
nutritional content of seagrasses, and with dugong physiological conditions such as age, sex, and reproductive status.

We examined temporal changes in the apparent digestibility of seagrass among captive dugongs, in relation to the nutritional content of seagrass and to dugong feeding parameters perhaps affecting the apparent digestibility of seagrass, based on re-analyses of the data obtained by Aketa et al. (2001).

\section{Materials and methods}

\section{Experimental animals}

Two dugongs, one female and one male, are kept at the Toba Aquarium (Mie, Japan) (Table 1), in separate pools (female: $9 \times 3.5 \times 3.2 \mathrm{~m}$, male: $10 \times 6.5 \times 3.2 \mathrm{~m}$ ) The female dugong has been in captivity for 10 years and the male for 21 years. Their body sizes and the length of their periods in captivity (Table 1), indicate that they are sexually mature (Marsh et al. 1984; Nishiwaki and Marsh 1985). According to Wakai et al. (2002), who studied the hormonal levels of the female dugong at Toba Aquarium from 1996 to 1998, the ovarian cycle takes nearly 50 days. During the present study, neither temporal variation in feeding parameters nor in digestibility of food indicated a relationship with the physiological condition of the female dugong.

The water temperature in the dugong pools was maintained at $28-30^{\circ} \mathrm{C}$ throughout the present study; salinity was not controlled but remained at 27.0-30.5 PSU.

The dugongs were fed only eelgrass Zostera marina twice a day, in the morning and in the late afternoon, which they ingested continuously for up to two hours. The eelgrass was harvested at Moppo, in southwestern Korea, and transported to the aquarium every 3-5 days. After arrival, eelgrass was stored at $3-5^{\circ} \mathrm{C}$ in a refrigerator before being fed to the dugongs.

\section{Measurement of apparent digestibility}

During the present study measuring the apparent digestibility of eelgrass by captive dugongs, the daily intake weight (DIW) was defined as the dry weight of eelgrass fed daily to the animals minus the amount of uneaten eelgrass remaining in their pools the following morning (see Table 2).

Eelgrass was weighed (ca. $1 \mathrm{~kg}$ ) after wiping off surface water using blotting paper, and its dry weight was obtained after drying it for one hour at $100^{\circ} \mathrm{C}$. The water content of eelgrass was calculated as the difference between the wet and dry weights. Both daily introduced weight (wet weight) (DIW), and daily intake rate (wet weight) (DIR (WW)), were recorded every day from September 1997 to October 1998, while the dry weight of daily introduced eelgrass (DIE), and the dry weight of the daily intake rate (DIR (DW)) were recorded every two weeks during the same period.

Previous studies (Lanyon and Marsh 1995; Kataoka 1997; Kataoka and Asano 1997) have indicated that food passes through the dugong gut in 144-168 hours, therefore we collected all feces excreted during the 24 hours from 144 to 168 hours after the dugongs were fed. Wet weights of feces were measured after removing surface

Table 1. Data on two dugongs in captivity at Toba Aquarium.

\begin{tabular}{ccccl}
\hline Sex & Body length $(\mathrm{cm})$ & Body weight $(\mathrm{kg})$ & Estimated age (yrs.) & Kept since \\
\hline Female & 244 & 345 & 10 & Apr. 15, 1987 \\
Male & 257 & 308 & 21 & Sep. 9, 1979 \\
\hline
\end{tabular}

Table 2. Abbreviation of terminology used in the present study.

\begin{tabular}{lll}
\hline \multicolumn{1}{c}{ Terminology } & Abbreviation & \multicolumn{1}{c}{ Unit } \\
\hline Daily Intake Weight (dry weight) & DIW & gDW/day \\
Daily Intake Energy & DIE & $\mathrm{kcal} /$ day \\
Daily Intake Rate (dry weight) & DIR (DW) & $\mathrm{DW} \%$ \\
Daily Intake Rate (wet weight) & DIR (WW) & $\mathrm{WW} \%$ \\
Daily Excreted Weight (dry weight) & DEW & $\mathrm{gDW} /$ day \\
Daily Excreted Energy & DEE & $\mathrm{kcal} /$ day \\
Apparent Digestibility of Dry Matter & ADD & $\mathrm{DW} \%$ \\
Apparent Digestibility of Energy & ADE & cal\% \\
\hline
\end{tabular}

$*:$ DIR $(D W)=[D I W / \text { daily introduced weight }(\text { dry weight })]^{*} 100, * *:$ ADD $=[(\mathrm{DIW}-$ $\mathrm{DEW}) / \mathrm{DIW}]^{*} 100, * * *: \mathrm{ADE}=[(\mathrm{DIE}-\mathrm{DEE}) / \mathrm{DIE}] * 100$ 
water from the feces using blotting paper. Fecal samples (ca. $300-500 \mathrm{~g}$ ) were frozen at $-30^{\circ} \mathrm{C}$ for later analysis. The dry weights of feces were measured twice, after drying for two hours at $100^{\circ} \mathrm{C}$ and then after drying for two hours at $80^{\circ} \mathrm{C}$. Fecal water content was calculated as the wet weight minus the dry weight. We used average wet and dry weights of feces, because the differences of these duplicate measurements ranged just $0.35-2.55 \%$ for the water content, and from 12.25 to $30.33 \mathrm{~g}$ for dry weights, and did not affect the apparent digestibility. The daily excreted weight (DEW) was calculated every two weeks from September 1997 to October 1998.

The energy contents of both the dried eelgrass and the feces were measured in duplicate using a bomb calorimeter (Shimazu Auto-Calculating Bomb Calorimeter: CA-4P). We used average energy contents because the differences between the duplicate measurements ranged only from 0.23 to $0.81 \mathrm{kcal} \cdot \mathrm{gDW}^{-1}$, and did not affect digestibility by dugongs. The water and energy contents of the eelgrass fed to the dugongs were measured once a week from September 1997 to October 1998, and daily excreted energy (DEE) was calculated based on the above measurements.

Following Van Soest et al. (1991), the neutral detergent fiber content (NDF), acid detergent fiber content and acid detergent lignin content of eelgrass were measured in duplicate once a month from March to December 1998. Average differences were used because the duplicate measurements ranged only from 0.30 $0.84 \% \mathrm{DW}$. Then, based on these data, proportions of cellulose, hemicellulose, and lignin were calculated. The crude protein content of eelgrass was measured in duplicate following the Kjeldahl method (Morimoto 1971). The crude protein content was also averaged because the duplicate measurements differed only by $0.21-1.10 \% \mathrm{DW}$.

Our measurements were deemed to be of "apparent" digestibility (based on dry matter (ADD) and energy $(\mathrm{ADE})$ ) in captive dugongs, because we have no information on the influence of intestinal bacteria on digestibility in sirenians. ADD and ADE were calculated every two weeks from September 1997 to October 1998 following Kleiber (1975).

\section{Results}

\section{Temporal variation in dugong feeding parameters}

There were significant differences between two periods of the female's DIW and also between two periods of the female's DIE (Mann-Whitney test, $P<$ 0.05): DIW and DIE were higher for the period from December 1997 to June 1998 (except for February 1998) and lower for the other period (Fig. 1). Except for February, this was also true of male DIW and DIE. Both DIW and DIE of the female, and probably of the male too, were apparently reduced in October 1997 and in February 1998 (Fig. 1). Except DIR (DW, WW) during October and November 1997, and DIR (DW) in January and also June 1998, DIR (DW, WW) for the female and the male remained nearly constant throughout the present study (Fig. 1). Similar to the temporal variations in DIW, DIE, and DIR (DW) (Fig. 1), there were significant differences between two periods of female DEW and also between two periods of female DEE (Mann Whitney test, $P<0.05$ ), those for the period from November 1997 to May 1998 contrasting with those after May 1998 (Fig. 2). The difference between the ratios of the DEE/DEW of the female and the male were not significant (Fig. 2), however, these ratios varied from September 1997 to May 1998, and then remained nearly constant (Fig. 2). The data on female ADD and ADE may be divided into two periods, they differed from November 1997 to May 1998, but they remained nearly constant after May (Mann-Whitney test, $P<0.05$ ) (Fig. 3). This was also true for male ADD and ADE.

The water and energy contents of the seagrass food remained nearly constant throughout the present study, the former being in a range of 86.4-91.6\% while the latter was in a range of $3.1-3.7 \mathrm{kcal} \cdot \mathrm{DW}^{-1}$ (Fig. 4). It is difficult to detect any temporal trends in either water or energy contents. The total fiber content (cellulose, hemicellulose and lignin) ranged from $34.1-43.1 \% \mathrm{DW}$, and remained nearly constant throughout the present study (Fig. 4). Cellulose content ranged from 8.3 to $25.2 \% \mathrm{DW}$ while lignin content ranged from 4.8 to $20.2 \% \mathrm{DW}$. Cellulose and lignin contents showed opposing temporal variation, while the hemicellulose content remained almost constant within the range 7.1-13.9\%DW (Fig. 4). In contrast, the crude protein content gradually decreased from March to July 1998, and then gradually increased with a range of 10.6-21.2\%DW (Fig. 4). Unfortunately, we have no data on the above parameters from September 1997 to March 1998, however, the lignin content was higher for the period from March to May 1998 when ADD and ADE were lower for both the male and female dugong, whereas it was lower for the period from June to October 1998 when ADD and ADE were higher for both the male and female dugongs. 

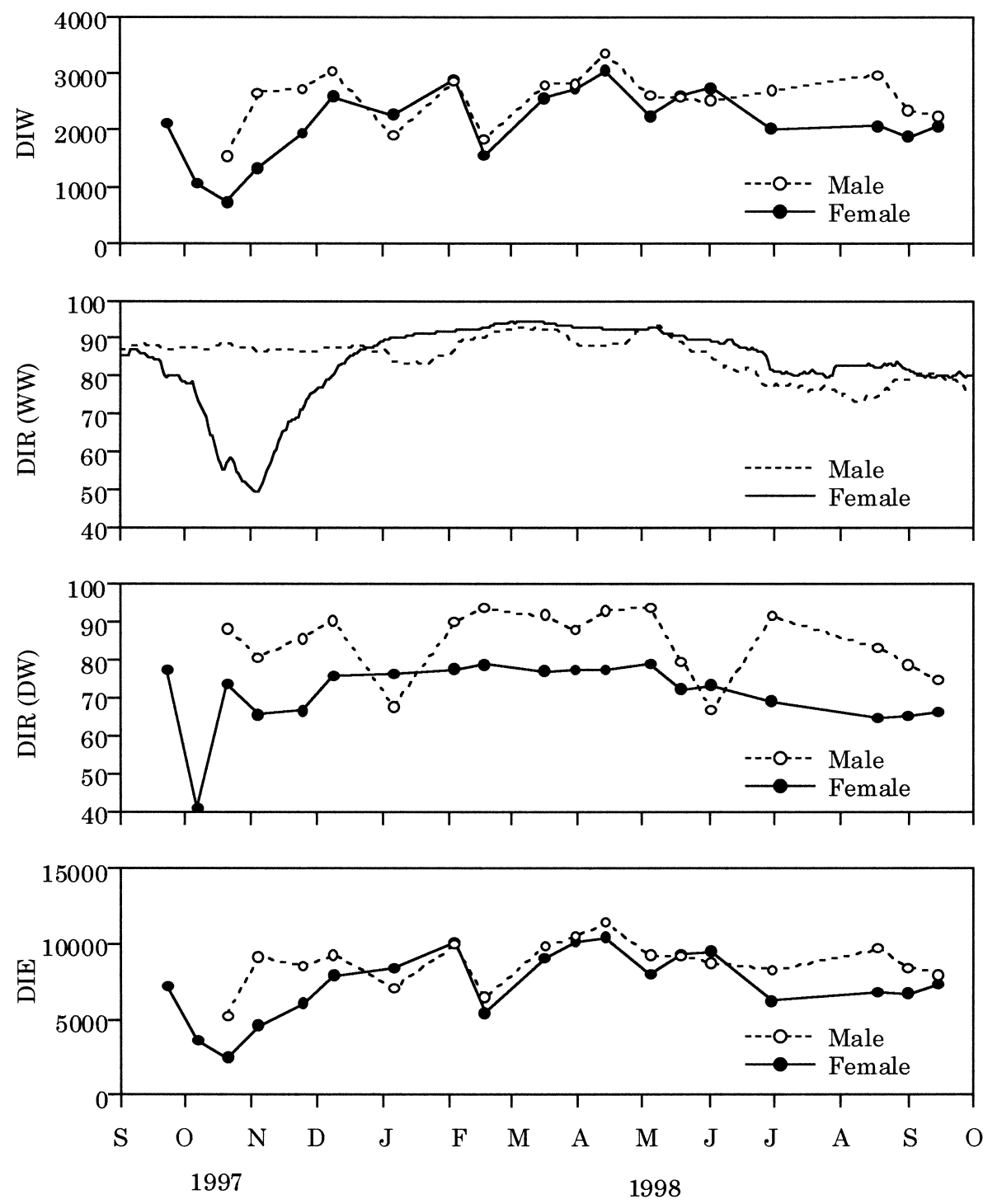

Fig. 1. Temporal variations of daily intake weight (DIW, gDW/day), daily intake rate (DIR (WW), WW\%; DIR (DW), DW\%), and daily intake energy (DIE, $\mathrm{kcal} /$ day), in female and male dugongs in captivity.

In summary, it is difficult to clearly detect any temporal trends in the above parameters in dugong feeding, as illustrated in Figs. 1-4.

\section{Relationships among dugong feeding parameters}

There were significant correlations between the wet and dry weights of the food provided daily for both the male and female dugongs $(r=0.88, n=19, P<0.05)$. For the female, there were significant correlations between dry weight of daily introduced weight and DIW, and between DIW and DIE ( $r=0.93$ and $0.98, n=19$, $P<0.05)$. However, there was no significant correlation between DIR (DW) and DIW, between DIR (DW) and DIE, between DIE and ADE, between ADD and DIW, between ADD and DIR (DW), and between ADD and dry weight of the food provided daily $(r=0.60,0.61$, $0.32,0.33,0.62$ and $0.15, n=19, P>0.05$ ).

For the male, there were significant correlations between dry weight of daily introduced weight and DIW, and between DIW and DIE ( $r=0.79$ and 0.84 , $n=17, P<0.05)$. However, there was no correlation between DIR (DW) and DIW, between DIR (DW) and DIE, between ADE and DIE, between ADD and DIW, between ADD and DIR (DW), and between ADD and the dry weight of the food provided daily $(r=0.31$, $0.24,0.04,0.11,0.46$ and $0.40, n=17, P>0.05$ ).

In summarizing, neither ADD nor ADE of both the male and female dugongs seemed to be strongly affected 

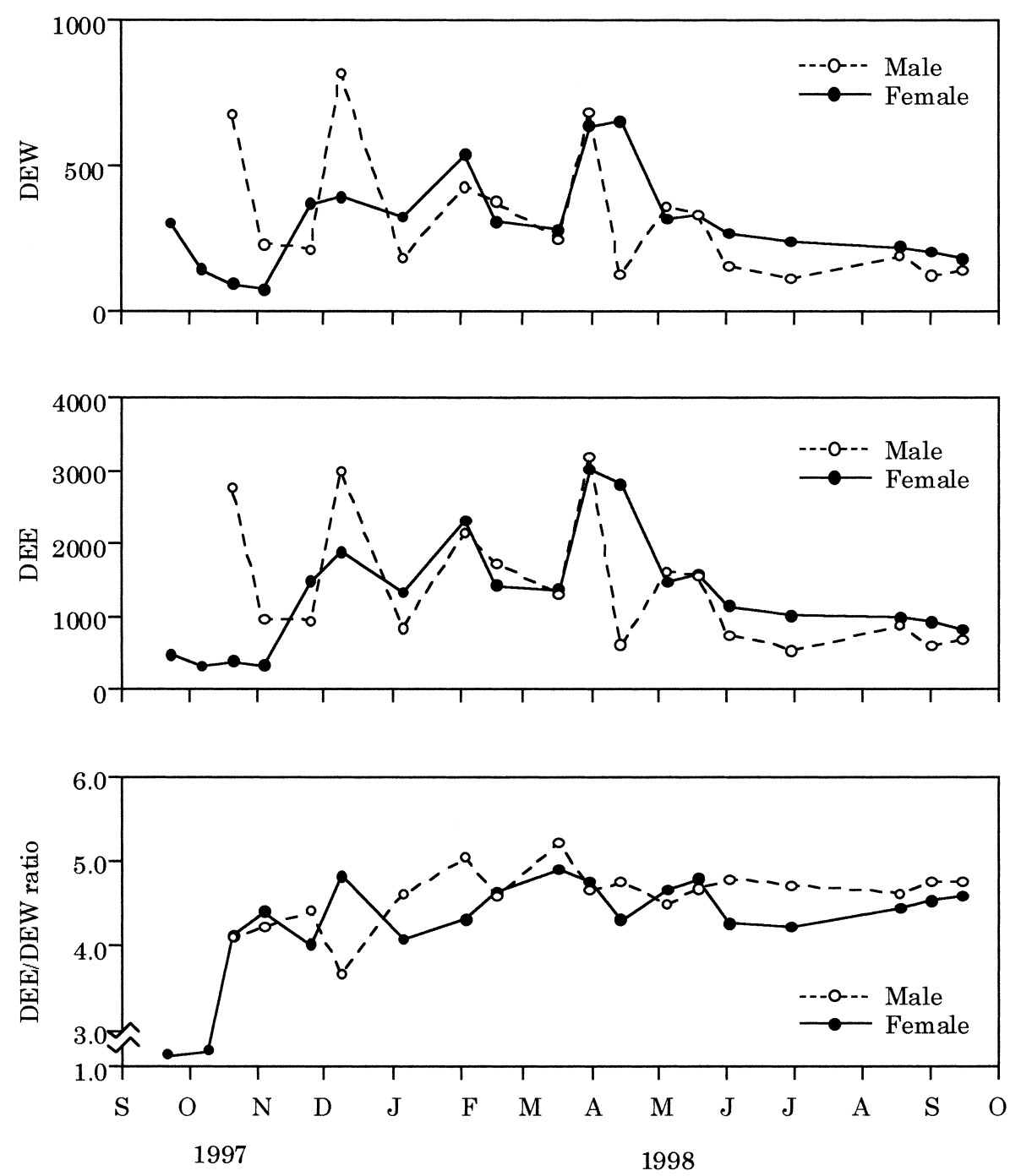

Fig. 2. Temporal variations of daily excreted weight (DEW, gDW/day), daily excreted energy (DEE, kcal/day), and DEE/DEW ratio, in female and male dugongs in captivity.

by either daily introduced weight, DIW, DIR and DIE. However, there was no significant correlation between ADD in either the male or female and the NDF content of eelgrass, between those and the cellulose content of eelgrass, or between those and the hemicellulose content of eelgrass (female: $r=-0.13,-0.24$ and 0.01 ; male: $r=0.10,0.68$ and $-0.17, n=7, P>0.05$ ). There was also no significant correlation between ADD in either the female or the male and the crude protein content of eelgrass $(r=-0.48$ and $-0.34, n=7, P>0.05)$. There was also no significant correlation between ADE in either the female or the male and the NDF content of eelgrass, between those and the cellulose content of eelgrass, between those and the hemicellulose content of eelgrass, and between those and the crude protein content of eelgrass (female: $r=-0.22,0.57,-0.07$ and -0.49 ; male: $r=0.20,-0.24,-0.01$ and $0.24, n=7, P>0.05$ ). However, there were significant correlations between $\mathrm{ADD}$ and $\mathrm{ADE}$ in both the male and female and the lignin content of eelgrass (female: $r=-0.81$ and -0.84 ; male: $r=-0.75$ and $-0.73, n=7, P<0.05)$.

In summary, both ADD and ADE in male and female dugongs may be affected strongly by the lignin contents of eelgrass.

\section{Discussion}

Several studies have been made of the apparent digestibility of food by sirenians, based on digestive tract analyses of dead individuals (Murray et al. 1977; Burn 1986) and on the food and feces of live individuals held in aquarium (Best 1981; Lomolino and Ewel 1984). 

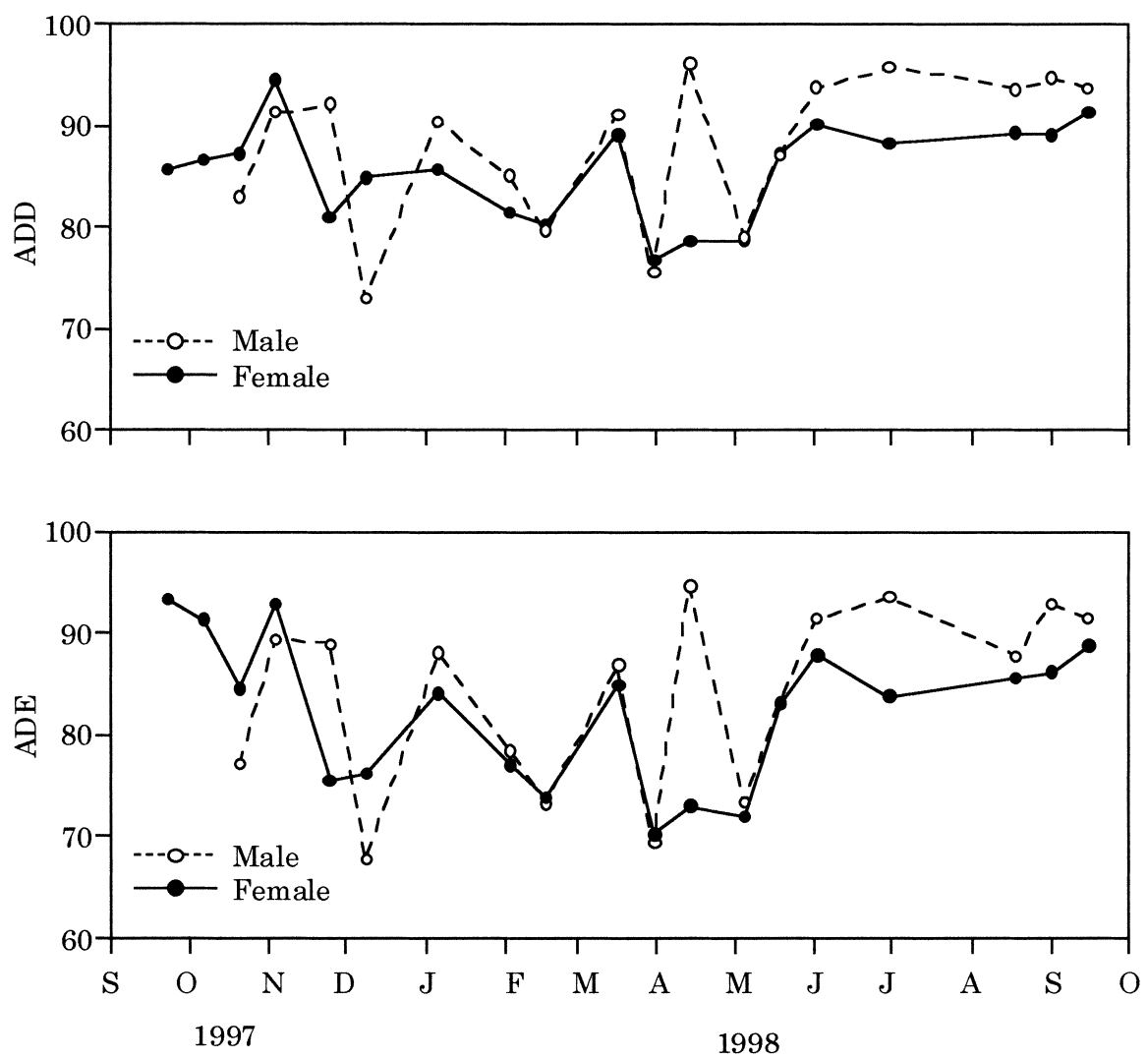

Fig. 3. Temporal variations of the apparent digestibilities based on dry matter (ADD, \%) and energy (ADE, \%), in female and male dugongs in captivity.

Lomolino and Ewel (1984) measured the apparent digestibility of water hyacinths Eichhornia crassipes and lettuce Lactuca lactuca in a West Indian manatee, based on fecal sampling for 24 hours from 146 to 170 hours after ingestion. They assumed that 146-170 hours was the food retention time of water hyacinths within the manatee digestive tracts based on the variation in the water hyacinth content of feces during the days after ingestion. Later studies, following Lomolino and Ewel (1984), have also estimated the food retention time of seagrass within the digestive tracts of dugongs to be 144-168 hours (e.g. Lanyon and Marsh 1995; Kataoka 1997; Kataoka and Asano 1997), based on the throughput of inert plastic markers and of indigestible plant material. We have no data on differences in food retention times in relation to dugong gender or season, so ignoring any possible differences we have assumed that the food retention time for captive dugongs was also 144-168 hours in this present study. ADD and ADE, calculated based on a food retention time with a range of 120-198 hours did not vary significantly.

The apparent digestibility exhibited by herbivorous mammals changes depending on the quantity and quality of their food (Robbins 1993; Aagnes et al. 1995, 1996). Daily food intake is determined by environmental factors such as temperature, day length, and food abundance (Mortensen and Blix 1989; Lager et al. 1994), as well as physiological factors such as growth, and reproduction (Kastelein et al. 1993, 1995). In the present study, environmental factors such as water temperature and salinity, as well as eelgrass quality, were the same for the male and the female. However, DIW and DIE in both the male and the female, as well as ADD and ADE, showed a pronounced temporal variation. Reproducibility of this trait needs to be checked in future work.

In the present study, there was a negative correlation between the lignin content of eelgrass and the apparent digestibility of eelgrass by captive dugongs. The lignin content of eelgrass may be one of the important factors affecting the apparent digestibility by dugongs, and this may also be true of the foods of other herbivorous mammals.

In general, herbivores show higher apparent digestibility of low fiber content such as cellulose than high fiber 

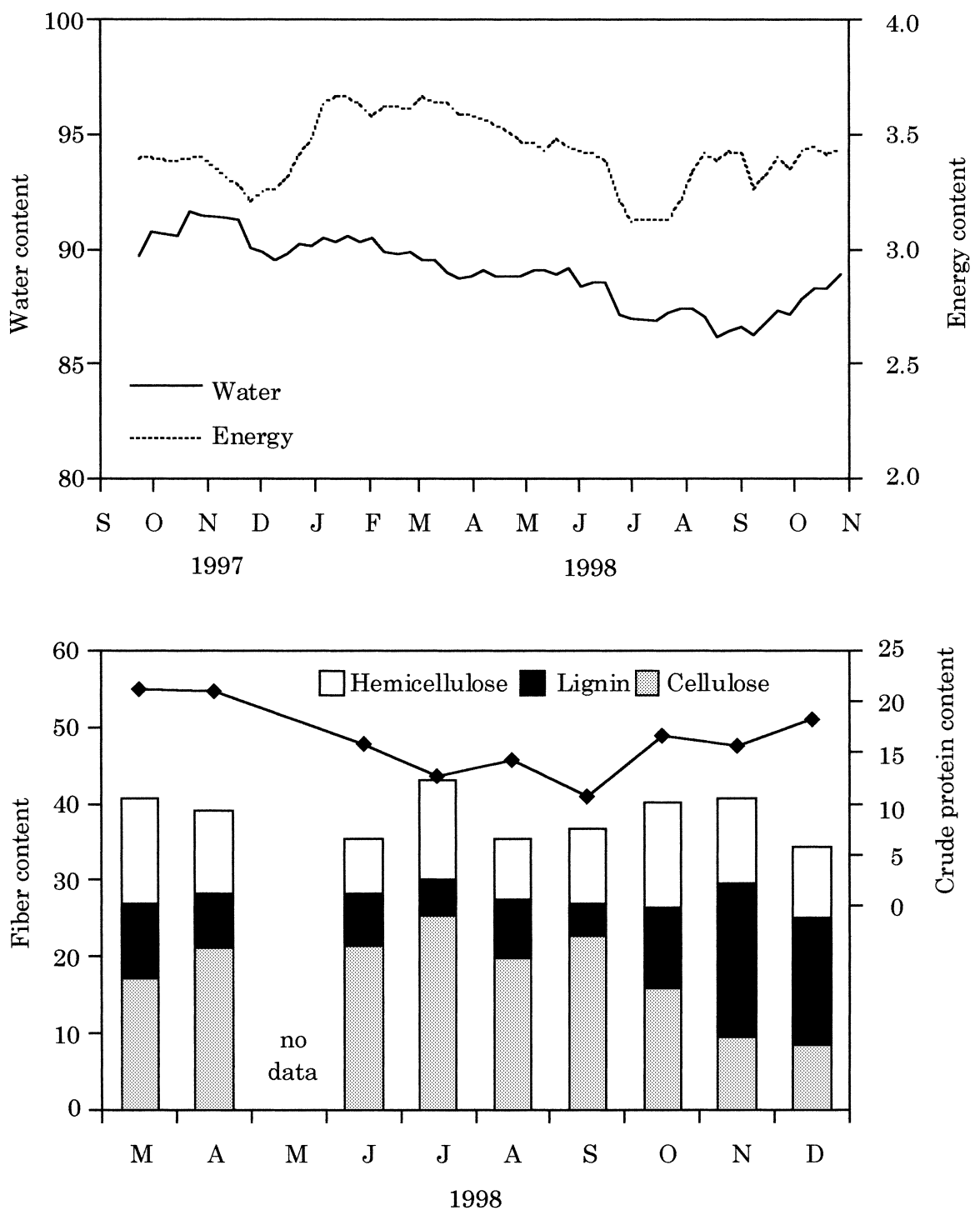

Fig. 4. Temporal variations of water $(\%)$, energy $\left(\mathrm{kcal}^{\mathrm{g}} \mathrm{gDW}{ }^{-1}\right)$, fibers (cellulose, hemicellulose, lignin, $\left.\% \mathrm{DW}\right)$ and crude protein $(\% \mathrm{DW})$ contents of eelgrasses introduced to female and male dugongs in captivity.

content such as lignin, which is one of the major components of fiber (Burn 1986). To our knowledge, however, no herbivorous mammal can digest lignin, even when aided by intestinal bacteria (Newsholme and Start 1973; Thayer et al. 1984), thus the lignin content is one of the most important factors affecting the apparent digestibility of seagrasses by herbivores (Burn 1986).

According to Murray et al. (1977), who examined the contents of the alimentary canal of a dead female dugong and used lignin as an indigestible marker, apparent digestibilities were estimated to be $70 \%$ for nitrogen, $63 \%$ for phosphorus, $84 \%$ for NDF, and $82 \%$ for acid detergent fiber. As indicated in Aketa et al. (2001) and also in the present study, the apparent digestibilities based on dry matter and energy (ADD and ADE) were in the range of $70.5-95.3 \%$ and $69.9-95.8 \%$, respectively. The digestibility of seagrasses, particularly of their fiber contents excluding lignin, may be much higher than previously recorded for the foods of any other herbivorous mammal, and thus a distinct characteristic of dugongs (Aketa et al. 2001). Although the nutritional composition of the eelgrass provided as food for the captive dugongs in the present study differed from the seagrass detected in the alimentary canal of the dead female examined by Murray et al. (1977), fiber contents are higher in seagrasses, including eelgrasses, than in terrestrial plants on which mammalian herbivores typically feed (Thayer et al. 1984). The above facts indicate that 
the captive dugongs in this study may have an extraordinarily high capacity to digest eelgrass, even though we may have underestimated the lignin contents of the food.

Acknowledgements: We express our sincere thanks to Messrs. H. Nakamura, T. Kataoka, M. Furuta and other staff of the Toba Aquarium for their encouragement of our experiments throughout the present study. We are grateful to Dr. H. Sekiguchi of Mie University, Dr. Christopher D. Marshall of the University of Washington, Dr. Mark A. Brazil of Rakuno Gakuen University, and two anonymous referees for their suggestions for improvements to our manuscript. Our thanks are also due to the late Dr. R. Tsuda, of Kinki University, for his encouragement to undertake our ongoing research.

\section{References}

Aagnes, T. H., Sørmo, W. and Mathiesen, S. D. 1995. Ruminal microbial digestion in free-living, in captive lichen-fed, and in starved reindeer (Rangifer tarandus tarandus) in winter. Applied and Environmental Microbiology 61: 583-591.

Aagnes, T. H., Blix, A. S. and Mathiesen, S. D. 1996. Food intake, digestibility and rumen fermentation in reindeer fed baled timothy silage in summer and winter. Journal of Agricultural Science, Cambridge 127: 517-523.

Aketa, K. 2003. The Study of Food and Digestive Characteristics in Sirenians. Ph. D thesis, Mie University, 110 pp. (in Japanese).

Aketa, K. and Kawamura, A. 2001. Digestive functions in sirenians (Review). The Bulletin of the Faculty of Bioresources, Mie University 27: 85-103 (in Japanese with English abstract).

Aketa, K., Asano, S., Wakai, Y. and Kawamura, A. 2001. Apparent digestibility of eelgrass in dugongs (Dugong dugon). Honyurui Kagaku [Mammalian Science] 41: 23-34 (in Japanese with English abstract).

Bertram, G. C. L. and Bertram, C. K. R. 1973. The modern sirenia: their distribution and status. Biological Journal of the Linnean Society 4: 297-338.

Best, R. C. 1981. Foods and feeding habits of wild and captive sirenia. Mammal Review 11: 3-30.

Burn, D. M. 1986. The digestive strategy and efficiency of the West Indian manatee, Trichechus manatus. Comparative Biochemistry and Physiology Part A 85: 139-142.

Erftemeijer, P. L., Djunarlin, A. and Moka, W. 1993. Stomach content analysis of a dugong (Dugong dugon) from south Sulawesi, Indonesia. Australian Journal of Marine and Freshwater Research 44: 229-233.

Harrison, P. C. and Mann, I. H. 1975. Chemical changes in eelgrass (Zostera marina) on the Atlantic coast of Canada. Journal of the Fisheries Research Board of Canada 32: 615-621.

Heinsohn, G. E. and Birch, W. R. 1972. Foods and feeding habits of the dugong, Dugong dugon (Erxleben), in northern Queensland, Australia. Mammalia 36: 414-422.

Johnstone, I. M. and Hudson, B. E. T. 1981. The dugong diet: mouth sample analysis. Bulletin of Marine Science 31: 681-690.

Kastelein, R. A., McBain, J., Neurohr, B., Mohri, M., Saijo, S., Wakabayahi, I. and Wiepkema, P. R. 1993. The food consumptions of Commerson's dolphins (Cephalorhynchus commersonii).
Aquatic Mammals 19: 99-121.

Kastelein, R. A., Kershaw, J., Berghout, E. and Wiepkema, P. R. 1995. The food consumption of South American sea lions (Otaria flavescens). Aquatic Mammals 21: 43-53.

Kataoka, T. 1997. Dugong. Kensei-sha, Tokyo, 179 pp. (in Japanese).

Kataoka, T. and Asano, S. 1997. The life of dugong. In (N. Miyazaki and T. Kasuya, eds.) Biology of Marine Mammals. Pp. 206-217. Scientist Inc., Tokyo (in Japanese)

Kleiber, M. 1975. The Fire of Life. Robert E. Krieger Publishing Co. Inc., New York, 312 pp.

Lager, A. R., Nordøy, E. S. and Blix, A. S. 1994. Seasonal changes in food intake of harp seals (Phoca groenlandica) at $69^{\circ} \mathrm{N}$. Marine Mammal Science 10: 332-341.

Lanyon, J. M. and Marsh, H. 1995. Digesta passage times in the dugong. Australian Journal of Zoology 43: 119-127.

Lomolino, M. V. and Ewel, K. C. 1984. Digestive efficiencies of the West Indian manatee (Trichechus manatus). Florida Scientist 47: 176-179.

Marsh, H., Channells, P. W., Heinsohn, G. E. and Morrissey, J. 1982. Analysis of stomach contents of dugongs from Queensland. Australian Wildlife Research 9: 55-67.

Marsh, H., Heinsohn, G. E. and Marsh, L. M. 1984. Breeding cycle, life history and population dynamics of the dugong, Dugong dugon (Sirenia: Dugongidae). Australian Journal of Zoology 32: 767-788.

Morimoto, H. 1971. Doubutsu eiyou shikenn hou. Yo-ken dou, Tokyo, $286 \mathrm{pp}$.

Mortensen, A. and Blix, A. S. 1989. Seasonal changes in energy intake, energy expenditure, and digestibility in captive Svalbard rock ptarmigan and Norwegian willow ptarmigan. Ornis Scandinavica 20: $22-28$.

Murray, R. M., Marsh, H., Heinsohn, G. E. and Spain, A. V. 1977. The role of the midgut caecum and large intestine in the digestion of sea grasses by the dugong (Mammalia: Sirenia). Comparative Biochemistry and Physiology Part A 56: 7-10.

Newsholme, E. A. and Start, C. 1973. Regulation in Metabolism. John Wiley \& Sons, London, $317 \mathrm{pp}$.

Nishiwaki, M. and Marsh, H. 1985. Dugong Dugong dugon (Müller, 1776). In (S. H. Ridgway and S. R. Harrison, eds) Handbook of Marine Mammals vol. 3. Pp. 1-31. Academic Press, London.

Ogawa, H. and Sensyu, T. 1986. Development of utilization of marine phanerogams - Basic studies on the evaluation of Zostera marina L. as animal feed 2. In (The Ito Foundation, ed.) Final Reports for Research Grants for Meat and Meat Products. Pp. 1-8. Sankyou-sha, Tokyo (in Japanese).

Robbins, C. T. 1993. Wildlife Feeding and Nutrition, 2nd ed Academic Press, San Diego, 352 pp.

Thayer, G. W., Bjorndal, K. A., Ogden, J. C., Williams, S. L. and Zieman, J. C. 1984. Role of larger herbivores in seagrass communities. Estuaries 7: 351-376.

Udén, P. and Van Soest, P. J. 1982. Comparative digestion of timothy (Phleum pratense) fibre by ruminants, equines and rabbits. British Journal of Nutrition 47: 267-272.

Van Soest, P. J., Robertson, J. B. and Lewis, B. A. 1991. Carbohydrate methodology, metabolism, and nutritional implications in dairy cattle-methods for dietary fiber, neutral detergent fiber, and non-starch polysaccharides in relation to animal nutrition. Journal of Dairy Science 74: 3583-3597.

Wakai, Y., Hasegawa, K., Sakamoto, S., Asano, S., Watanabe, G. and Taya, K. 2002. Annual changes of urinary progesterone and estradiol-17fl of the dugong (Dugong dugon) in captivity. Zoological Science 19: 679-682.

Received 19 June 2002. Accepted 6 January 2003. 